\title{
Nowe odkrycie w krach mezozoicznych w okolicach Lukowa i jego znaczenie dla promocji geoturystycznej regionu
}

\author{
Andrzej Wierzbowski ${ }^{1}$, Michal Świder ${ }^{2}$, Monika Krzeczyńska ${ }^{3}$, Wojciech Szczygiel ${ }^{4}$
}

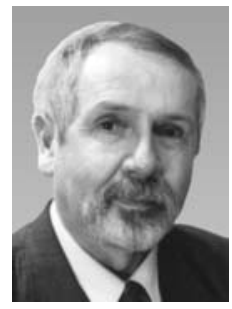

A. Wierzbowski

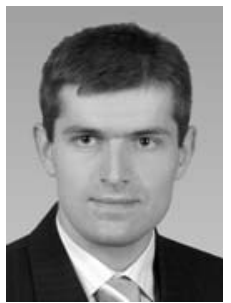

M. Świder

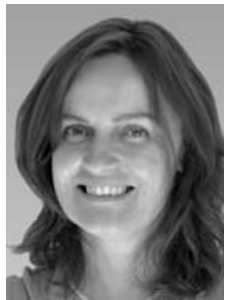

M. Krzeczyńska

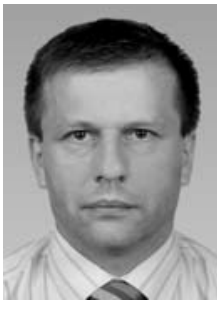

W. Szczygieł

New discovery in glacially transported Mesozoic rock masses at Luków (eastern Poland), and its importance for the geotouristic promotion of the region. Prz. Geol., 66: 706-712; doi: 10.7306/2018.13

A b s tract. An excavation dug out in the glacially transported rock masses at Gołaszyn near Łuków (eastern Poland), revealed the presence of deposits unknown so far in this area. These are older than the only known so far here glacially transported clays containing concretions with splendidly preserved ammonites of late Callovian at Lapiguz brickyard of Łuków. The succession exposed consists of sands and sandstones of Middle Callovian age which rest on red-brownish clays. The latter may be compared with the Triassic - Buntsandstein deposits of the northwestern Lithuania, that is the home area of glacially transported rock masses, commonly occurring in eastern Poland in the Euków area. The new geological discoveries markedly increase a set of attractions for the promotion of the Euków region for the education and geotourism purposes.

Keywords: glacially transported deposits, Euków, Gołaszyn, Jurassic, Middle Callovian, sandstones, Triassic, Buntsandstein, clays

Osady jurajskie z kier glacjalnych w okolicach Łukowa, opisane szerzej po raz pierwszy przez Nikołaja Krisztafowicza (Krisztafowicz, 1896), od ponad 120 lat budzą zainteresowanie badaczy oraz kolekcjonerów skamieniałości i nadal stanowią duży potencjał turystyczny regionu. W wyniku wieloletnich badań geologicznych przeprowadzonych w okolicach Łukowa i w samym mieście stwierdzono obecność prawdopodobnie co najmniej 12 kier jurajskich (ryc. 1). Istniejące glinianki, zwłaszcza najsłynniejsza z nich na Łapiguzie w Łukowie, dostarczyły w przeszłości bogatych kolekcji wspaniale zachowanych skamieniałości. Występują one zwłaszcza w konkrecjach węglanowych, wśród czarnych iłów z dużą domieszką materiału aleurytowego zaliczanych do keloweju, a więc najwyższego piętra jury środkowej. Iły te były wydobywane do celów ceramicznych, a zawarte w nich konkrecje z licznymi skamieniałościami odrzucano jako zanieczyszczenie. Ostatecznie cegielnia na Łapiguzie została zamknięta w 1975 r. (Zarzycki, 1989, 1996), a wyrobiska są w całości wypełnione wodą. Nie ma dostępu do występujących tam osadów oraz zawartej w nich fauny.

Stan geologiczny wyrobiska został szczegółowo przedstawiony w starszych pracach - zwłaszcza opracowaniu Jahna (1950), który omówił następstwo utworów plejstoceńskich - w szczególności glin zwałowych, podścielających i przykrywających występujące tu utwory jurajskie. Wykonane w latach późniejszych liczne wiercenia (Morawski, 1955) wykazały, że maksymalna grubość jurajskich skał ilastych występujących wśród utworów plejstoceńskich wynosi ok. 9-10,5 m (maksymalnie $12 \mathrm{~m}$ ). Inna kra (lub zespół trzech kier) występuje bezpośrednio na północny zachód od Łukowa w miejscowości Gołaszyn.
Osady jurajskie zostały tu rozpoznane wierceniami (Kosmulska, 1973; Mizerski i Szamałek, 1985, częściowo w nawiązaniu do niepublikowanego opracowania A. Piątkiewicza z 1972 r.). Miąższość utworów zaliczanych do jury, występujących wśród utworów plejstoceńskich, była zmienna i wahała się w wierceniach od kilku do maksymalnie $25,8 \mathrm{~m}$. Z przedstawionych we wspomnianych pracach badań wynika, że pod nadkładem glin zwałowych badź piasków zglinionych nawiercono ity jurajskie czarne, ciemnoszare i brunatne, zwierajace buty sferosyderytowe oraz iły wiśniowe o dużej zawartości utlenionych zwiazków żelaza i pelitu węlanowego (Kosmulska, 1973, s. 440). Z kolei wg Mizerskiego i Szamałka (1985, s. 371-372) w otworze wiertniczym (...) znajdujacym się $w$ centrum kry, stwierdzono przewarstwianie się utworów kelowejskich z osadami czwartorzędowymi na odcinku około $10 \mathrm{~m}$ - przy czym we wskazanym przez autorów wierceniu na ich figurze 4, występują na omawianym odcinku: piaski, iły wiśniowe i iły czarne. Wszystkie te obserwacje wskazują na złożoną budowę łukowskich kier glacjalnych, co potwierdza także przeprowadzona ostatnio metodą elektrooporową analiza geofizyczna (Mendecki i in., 2018).

Prawie wszystkie opisane dotąd skamieniałości z osadów jurajskich z kier okolic Łukowa pochodziły z cegielni na Łapiguzie, przede wszystkim z wczesnodiagenetycznych konkrecji węglanowych, sferycznych w kształtach, osiągających od kilku do nawet $30 \mathrm{~cm}$ średnicy. Konkrecje te nie były szczegółowo lokalizowane w profilu, a ich rozmieszczenie w osadach ilastych nie było przywiązane do określonego poziomu (Makowski, 1952). Sądząc z profilu osadów jurajskich przedstawionego przez Jahna (1950), mogły one pochodzić z odsłoniętych tu iłów o przeciętnej

\footnotetext{
${ }^{1}$ Wydział Geologii, Uniwersytet Warszawski, ul. Żwirki i Wigury 93, 02-089 Warszawa; andrzej.wierzbowski@uw.edu.pl

${ }^{2}$ Zespół Szkół Nr 3 im. W.S. Reymonta w Łukowie, ul. Międzyrzecka 70, 21-400 Łuków; mswid@wp.pl

3 Państwowy Instytut Geologiczny - Państwowy Instytut Badawczy, ul. Rakowiecka 4, 00-975 Warszawa; mkrz@pgi.gov.pl

${ }^{4}$ Urząd Gminy Łuków, ul. Świderska 12, 21-400 Łuków; wojtekszczygiel@interia.pl
} 


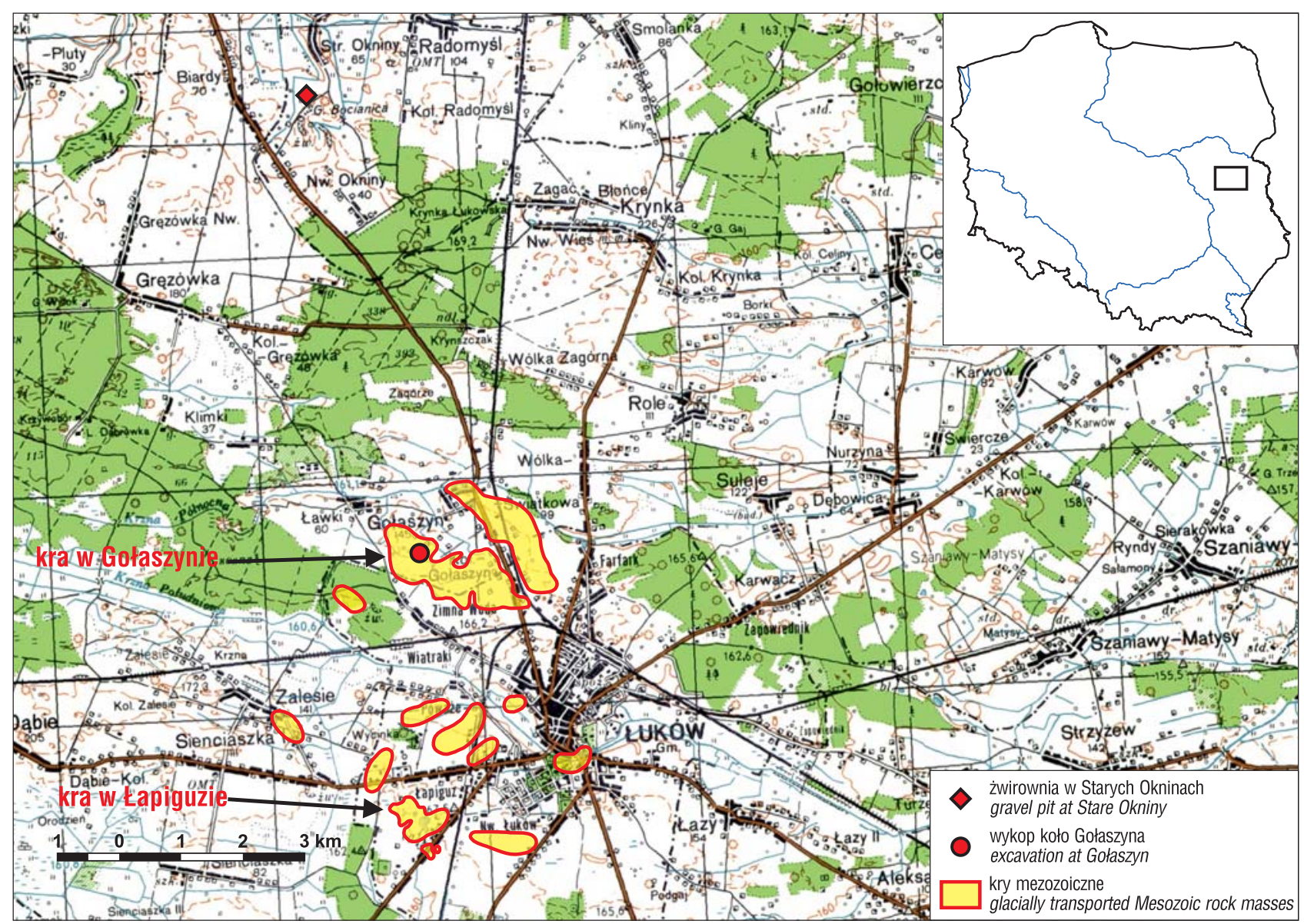

Ryc. 1. Kry mezozoiczne w Łukowie i okolicach (wg Małek i Maleszyk, w: Gałązka i in., 2009)

Fig. 1. Glacially transported Mesozoic rock masses at Łuków and its surroundings (after Malek and Maleszyk, in: Gałązka et al., 2009)

grubości ok. $3 \mathrm{~m}$, a więc zawarta w nich fauna jurajska reprezentowała jedynie fragment całości profilu osadów jurajskich, stwierdzonych wierceniami w okolicach Łukowa. Skamieniałości jury są doskonale zachowane i reprezentują bardzo zróżnicowany świat roślinny (napławione fragmenty drewna drzew iglastych, cysty morskich bruzdnic) i zwierzęcy (otwornice, ramienionogi, serpule, mszywioły, skorupiaki - małżoraczki, ślimaki, małże, amonity, łodziki, belemnity, różnorakie szkarłupnie - liliowce, rozgwiazdy, wężowidła i strzykwy, a nawet pióroskrzelne Rhabdopleura). Wszystkie te skamieniałości zostały szczegółowo opracowane w ponad 35 publikacjach naukowych oraz wielokrotnie wzmiankowane w innych specjalistycznych pracach. Nie ma tu miejsca na szczegółowy opis tych znalezisk, chociaż rozsławiły one Łuków jako jedno z ważniejszych jurajskich stanowisk paleontologicznych w Europie [por. szerszy komentarz: od najbardziej klasycznej monografii Makowskiego (1952) po sumaryczne zestawienie rezultatów badań paleontologicznych w pracach Salamona i Zatonia (2008) - stanowiących wprowadzenie do specjalnego tomu Neues Jahrbuch für Geologie und Paläontologie, poświęconego geologii i paleontologii jury łukowskiej, oraz Zatonia (2011)].

Szczególne znaczenie okazom łukowskim zapewniły studia paleontologiczne doskonale zachowanych muszli amonitów, które stały się podstawą do przedstawienia znanej teorii dymorfizmu płciowego u tych zwierząt, wyjaśniającej istnienie dwóch morf o różnej wielkości i początkowo podobnej ornamentacji muszli (Makowski, 1962), czy też konkurencyjnej teorii polimorfizmu rozwojowego
(Matyja, 1986), zakładającej zróżnicowanie wielkości muszli o początkowo podobnej morfologii, wskutek wcześniejszego lub późniejszego dojrzewania zwierzęcia w związku ze zmianami zachodzącymi w otaczającym środowisku. Doskonały stopień zachowania muszli amonitów stał się także podstawą do przeprowadzenia szczegółowych badań nad rozwojem i funkcjami życiowymi tych wymarłych głowonogów (Kulicki, 1979, 1996 i inne cytowane tam prace). Wreszcie niezmieniony diagenetycznie zapis izotopów tlenu w aragonitowej muszli amonitów łukowskich pozwolił na określenie temperatury dawnej wody morskiej i jej zasolenia (Brand, 1986).

Szczegółowa analiza stratygraficzna pochodzących z cegielni Łapiguz amonitów przedstawionych przez Makowskiego (1952), uwzględniająca częściową rewizję niektórych oznaczeń (Arkell, 1956, s. 481-482; Callomon, Wright, 1989), sugeruje istnienie tu dwóch zespołów amonitów - starszego prawdopodobnie z wyższej części chronostratygratygraficznego poziomu amonitowego Athleta - zwłaszcza podpoziomu Spinosum, oraz młodszego z niższej części poziomu Lamberti - podpoziomu Henrici. Wynika stąd, że odsłonięte niegdyś w cegielni Łapiguz iły odpowiadały generalnie środkowej części górnego keloweju, a więc prezentowały wąski przedział stratygraficzny. W tej sytuacji zasadnym stało się pytanie, czy wszystkie osady występujące w krach k. Łukowa są rzeczywiście tego samego wieku (Wierzbowski, 2018).

W ogólniejszych rozważaniach dotyczących łukowskich kier glacjalnych zasadnicze znaczenie ma także ich miejsce pochodzenia. Podzielone zdania w tym zakresie, 
w niedalekiej przeszłości, wynikały przede wszystkim z niepełnej analizy osadów występujących w krach, bądź też przywiązywania nadmiernej wagi do znaleziska pojedynczej konkrecji z amonitami typu „łukowskiego”, w niejasnej sytuacji geologicznej w zachodniej części Szwecji, w Skanii. Analiza charakteru osadów jurajskich występujących w rejonie Łukowa, a także towarzyszących im w glinach zwałowych eratyków przewodnich, wyraźnie wskazuje na związek łukowskich kier jurajskich z tzw. mazurskim strumieniem lodowym zlodowacenia odry. Fakt ten oraz występowanie w rejonie Łukowa grubych osadów ilastych keloweju (zwłaszcza keloweju górnego), wyznaczają obszar północno-zachodniej Litwy, a w szczególności okolice Kłajpedy, jako pierwotne miejsce pochodzenia kier (Gałązka, 2004; Gałązka i in., 2009; por. także Wierzbowski, 2018). Konsekwencją takiej interpretacji stała się również konieczność zwrócenia uwagi, czy w okolicach Łukowa nie występują także inne osady mezozoiczne, znane z północno-zachodniej Litwy.

Celem artykułu jest przedstawienie nowego odkrycia w krach mezozoicznych w okolicach Łukowa na tle dotychczasowych badań oraz ukazanie jego znaczenia dla rozwoju geoturystycznego regionu.

\section{NOWE OBSERWACJE I ICH INTERPRETACJA}

W związku z organizacją na początku września b.r. w Łukowie 86. Zjazdu Naukowego Polskiego Towarzystwa Geologicznego, stanowiącego część szerszego planu połączonych działań naukowych i geoturystycznych Gminy Łuków i środowiska geologicznego (działania te zostaną omówione bardziej szczegółowo w ostatnim rozdziale opracowania), zaistniała konieczność zbadania kier jurajskich i ich bezpośredniego sąsiedztwa, w celu szczegółowego rozpoznania występujących tam skał. Dwóch autorów opracowania (M.Ś. i A.W.) odwiedziło w lipcu 2018 r. kilka żwirowni i innych odsłonięć osadów plejstoceńskich $\mathrm{w}$ okolicach Łukowa, gdzie poddano analizie występujący tam materiał skalny. W bezpośrednich okolicach Gołaszyna w płytkich wykopach wśród utworów plejstoceńskich (warciańskich) (Małek, Buczek, 2011) napotkano fragmenty ostrokrawędzistych, słabo wapnistych drobnoziarnistych piaskowców kwarcowych, a w żwirowni w starych Okninach (w osadach warciańskich; Małek, 2002) - ok. 30-centymetrowej średnicy kanciasty blok kruchego, wapnisto-żelazistego piaskowca z oolitami żelazistymi i bardzo liczną fauną małżów oraz ułamkiem amonita - prawdopodobnie z rodzaju Kosmoceras - niewątpliwie wieku kelowejskiego. Znaleziska te najprawdopodobniej pochodziły z rozmywania osadów jurajskich występujących w pobliskich krach - znanej w okolicach Gołaszyna, oraz nierozpoznanej dotąd, lecz dość prawdopodobnej, w okolicach Starych Oknin. Wskazały one ewidentnie na możliwość występowania w bezpośredniej okolicy skał odmiennych, niż znane dotąd ilaste osady keloweju z kier Łukowa.

$\mathrm{Z}$ gminnych środków finansowych, na działce Gminy Łuków, w strefie występowania kry jurajskiej w Gołaszynie, w dniu 28 sierpnia 2018 r. został wykonany głęboki wykop. Usytuowano go niedaleko starszego wykopu (ok. $2 \mathrm{~m}$ w kierunku zachodnim) wykonanego w 2017 r., sięgającego czarnych iłów keloweju i ułożonego w linii elektrooporowego profilu geofizycznego $\mathrm{nr} 4$ wykonanego przez Mendeckiego i in. (2018, ryc. 7).
Wykonany wykop odsłonił, w obecności autorów niniejszego opracowania, następstwo prawie płasko zalegających, nieznanych dotąd $\mathrm{z}$ okolic Łukowa utworów, łagodnie nachylonych pod kątem kilku stopni w kierunku północnym (ryc. 2). Najstarsze są czerwone iły z drobnymi blaszkami muskowitu i sporadycznymi przeławiceniami mułowców, o co najmniej kilku metrach miąższości. Wyżej stratygraficznie leży warstwa drobnoziarnistych piasków kwarcowych, zawierających drobne, brunatne skupienia związków żelaza (ooidy żelaziste?). Piaski są w dole jasnoszare, wyżej - ponad cienką warstwą słabo wapnistych iłów piaszczystych - ciemnoszare, zailone; miąższość warstwy piasków (warstwa 1 na ryc. 2) wynosi ok. $45 \mathrm{~cm}$. Powyżej występuje bardzo wyraźna, dwudzielna warstwa wapnistych piaskowców żelazistych z obfitą fauną (warstwa 2), o miąższości ok. $60 \mathrm{~cm}$. W niższej części warstwy (2a-ryc. 3A; 4 - patrz okładka główna) występują drobnoziarniste, twarde piaskowce kwarcowe z nagromadzeniami fauny małżowej w cienkich smużkach. W wyższej części warstwy $(2 \mathrm{~b}$ - ryc. 3B, D) piaskowce są przeważnie drobno- i średnioziarniste, chociaż spotyka się też pojedyncze ziarna żwiru. Licznie występują ziarna kwarcu wykazujące bardzo zmienny stopień obtoczenia, lecz także (choć w zmiennych ilościach) ooidy żelaziste oraz nieregularne skupienia związków żelaza. W skale spotyka się powszechnie doskonale zachowane muszle małżów (m.in. z rodzajów Astarte, Protocardia, Anisocardia, Trigonia, Gervillia, a także z rodzin Ostreidae i Pectinidae), rzadziej ślimaków, amonitów (m.in. z rodzaju Erymnoceras - ryc. 3C), kawałki drewna, a także okruchy fosforytów. Okruchy piaskowców pochodzących z plejstoceńskich utworów w okolicach Gołaszyna są podobne do piaskowców z niższej części warstwy (2a), a okruchy piaskowców ze żwirowni w Starych Okninach są podobne do piaskowców z wyższej części warstwy (2b). Młodsze utwory napotkane w omawianym wykopie w Gołaszynie to żółtobrunatne iły piaszczyste $\mathrm{z}$ cienkimi przeławiceniami silnie wapnistych piaskowców z ziarnami kwarcu, ooidami żelazistymi i ułamkami muszli małżów, utwory te mają ok. $30 \mathrm{~cm}$ miąższości (warstwa 3). Najmłodsze utwory w wykopie są reprezentowane przez szare i ciemnoszare, silnie zwietrzałe iły ze znaczną domieszką ziaren frakcji pyłowej oraz z detrytusem muszlowym. Spotyka się tu drobne, kilkucentymetrowej średnicy konkrecje węglanowe (ryc. 5 - patrz str. 714). Niepełna miąższość tej warstwy (warstwa 4) wynosi ok. $50 \mathrm{~cm}$.

Chociaż szczegółowa analiza zebranego materiału wymaga szeregu specjalistycznych badań i będzie przedstawiona w przyszłości, już obecnie można sformułować kilka ogólniejszych wniosków.

Prawie wszystkie opisane wyżej utwory (poza warstwą 4) nie mają żadnego odpowiednika wśród znanych dotąd skał mezozoicznych okolic Łukowa. Ich interpretacja może być dokonana zarówno na podstawie znalezionych w nich skamieniałości, jak też ich podobieństwa do osadów w północno-zachodniej Litwie, zwłaszcza w okolicach Kłajpedy, stanowiących oryginalny zachowany obszar wychodni dla wyrwanych stąd kier łukowskich. Amonity z rodzajów Erymnoceras i Kosmoceras znalezione w piaskowcach wyższej części warstwy 2 w wykonanym wykopie w Gołaszynie wskazują na środkowy kelowej - zwłaszcza poziom chronostratygraficzny Coronatum. Osady te sa zatem wyraźnie starsze od znanych dotąd z okolic Łukowa 


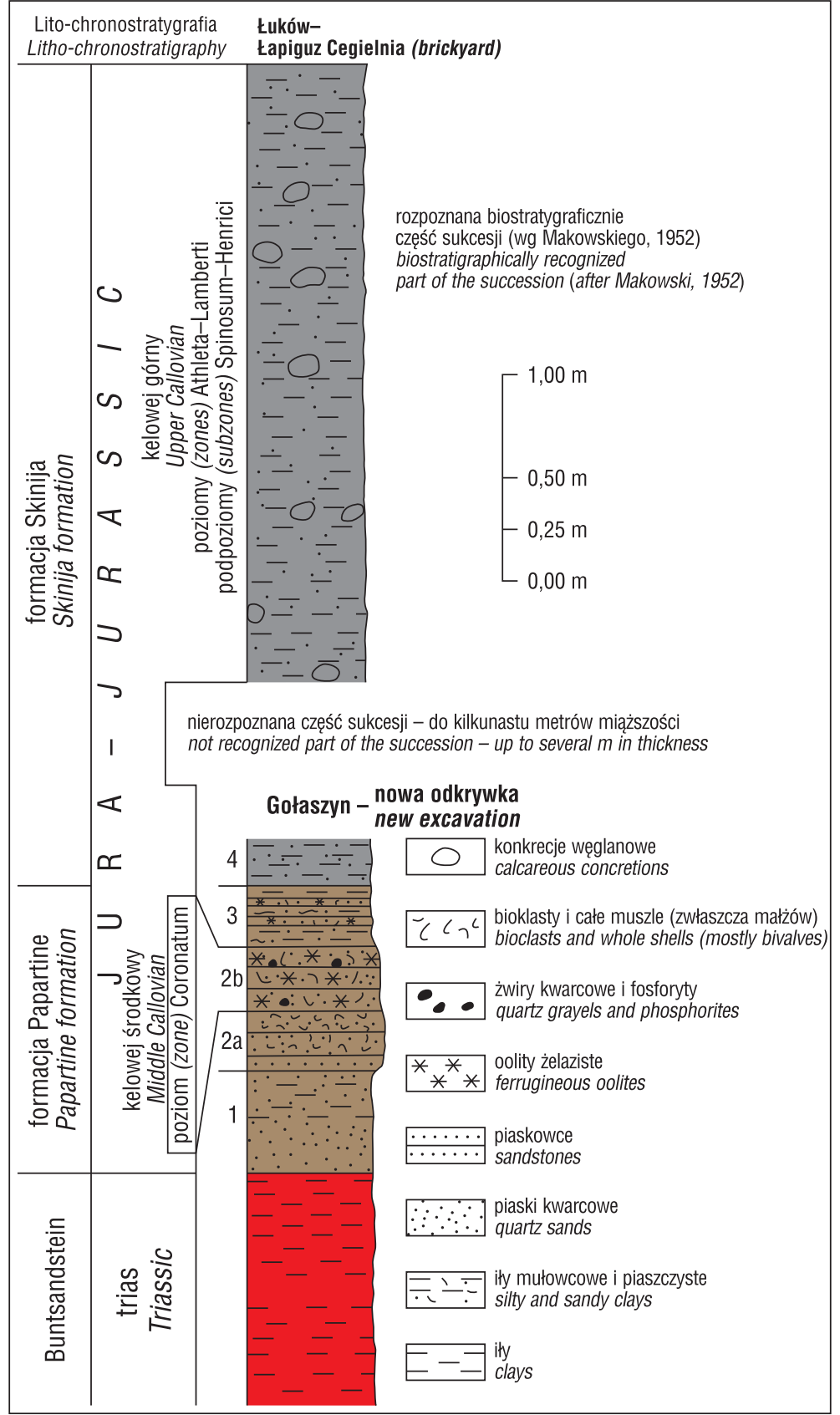

Ryc. 2. Następstwo utworów w krach mezozoicznych Łukowa i Gołaszyna i interpretacja lito- i chronostratygraficzna. Kolory skał w profilu są zgodne $\mathrm{z}$ ich naturalną barwą

Fig. 2. Succession of deposits in the glacially transported Mesozoic rock masses at Łuków and Gołaszyn and its litho- and chronostratigraphical interpretation. Rocks in the lithostratigraphical column are marked in their natural colours

iłów z konkrecjami węglanowymi, zaliczanych do górnego keloweju. Występujące ponad piaskowcami warstwy ilaste z wkładkami piaskowców (warstwa 3) oraz leżące nad nimi iły (warstwa 4) mogą stanowić zatem przejście do grubego kompleksu ilastego górnego keloweju. Z kolei osady starsze - piaski (warstwa 1) nawiązują litologicznie do osadów piaszczystych warstwy 2 i są wyraźnie odmienne od występujących niżej czerwonych iłów z podrzędnymi wkładkami mułowców (ryc. 2; 5 - patrz str. 714).

W profilach okolic Kłajpedy, bezpośrednio pod grubym zespołem iłów odnoszonych do górnego keloweju i wyróżnianych jako formacja Skinija, występują osady piaszczyste $\mathrm{i}$ oolitowe bogate $\mathrm{w}$ faunę wskazującą zwłaszcza na środkowy kelowej, $\mathrm{z}$ doskonale udokumentowanymi poziomami amonitowymi Jason i Coronatum, zaliczane do formacji Papartiné (Grigelis, Norling, 1999; także opis w: Rotkyte, 1987 oraz starsze cytowane tam prace). Właśnie osady piaszczyste warstw 1-3 z nowego wykopu w Gołaszynie mogą być korelowane z formacją Papartiné, podczas gdy leżące wyżej iły (warstwa 4) mogłyby reprezentować najniższą część formacji Skinija.

Poniżej wspomnianych osadów formacji Papartiné w okolicach Kłajpedy występują osady niższego triasu wykształcone jako różnorodne osady siliciklastyczne, przede wszystkim iły i mułowce o dominujących czerwono-brazowych barwach (Iwanow i in., 1998; Grigelis, Norling, 1999). Chociaż brak jest obecnie jednoznacznych paleontologicznych dowodów na wiek czerwonych iłów z najniższej części wykopu w Gołaszynie (pojedyncze próby analizowane dzięki uprzejmości Marcina Barskiego i Adama Gasińskiego okazały się płone), ich podobieństwo litologiczne i sytuacja w profilu dość istotnie sugerują, że mogą one odpowiadać triasowi w facji pstrego piaskowca, a także być korelowane z niższym triasem z okolic Kłajpedy (por. Iwanow i in., 1998). Potwierdzenie tego przypuszczenia wymaga dodatkowych badań, przede wszystkim palinostratygraficznych, jednakże już obecnie wydaje się bardzo prawdopodobne, że mezozoiczne kry okolic Łukowa reprezentują nie tylko osady jury środkowej, lecz także niższy trias. Nowe znaleziska w wykopach w Gołaszynie doprowadziły zatem do odkrycia nieznanej dotąd, niższej części mezozoicznej sukcesji kier łukowskich.

Nawiązując do wykonanego wkopu w Gołaszynie, możemy przedstawić jeszcze jedna, dość istotną informację. Ponad opisaną powyżej sukcesją (por. ryc. 2), przy rozszerzaniu wykopu w kierunku północnym pojawiły się jeszcze raz czerwone iły, które mogą być odniesione do triasu (ok. 0,5 m miąższości), a wyżej, ponad resztkowo zachowaną warstwą piaszczystą (fragmenty warstw 1-3), jeszcze raz zaobserwowano ciemnoszare iły jurajskie (o miąższości minimum 1,20 m) (ryc. 6, 7 - patrz str. 714). Podobne powtarzające się następstwo warstw zostało rozpoznane $\mathrm{w}$ wierceniu $\mathrm{z}$ okolic Gołaszyna opisanym przez Mizerskiego i Szamałka (1985, fig. 4). Omawiane następstwo może wynikać z glacitektonicznych deformacji osadów kry jeszcze w stanie zmarzniętym, gdy poszczególne pakiety skalne zostały glacitektonicznie przemieszczone i nasunięte na siebie. Obserwacje te dodatkowo potwierdzają złożoną budowę wewnętrzną kier łukowskich.

\section{ZNACZENIE KIER LUKOWSKICH DLA PROMOCJI GEOTURYSTYCZNEJ REGIONU}

Poza wartością naukową, skamieniałości jurajskie występujące w krach łukowskich odznaczają się szcze- 


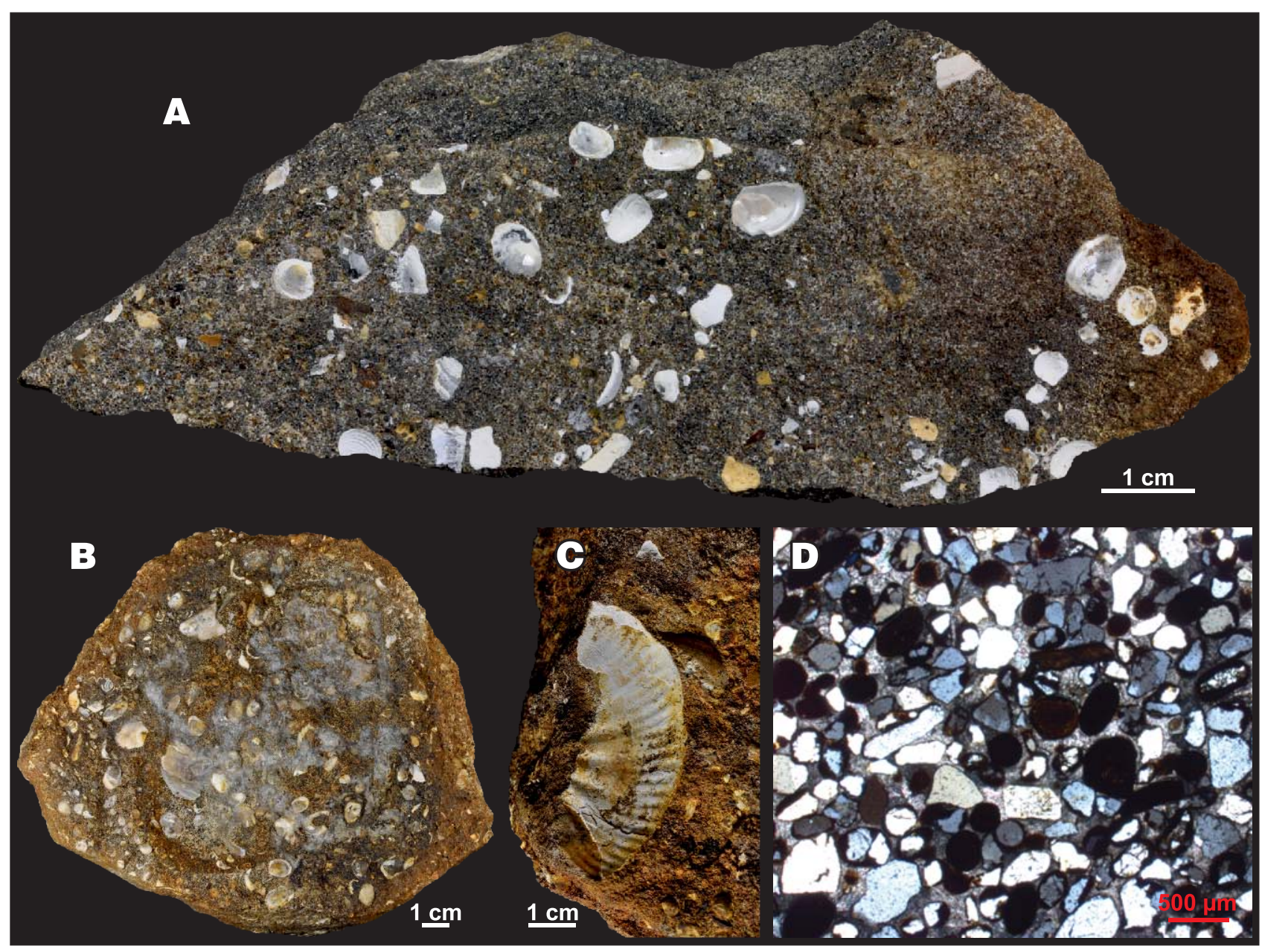

Ryc. 3. Piaskowce środkowego keloweju i fauna z warstwy 2 z wykopu w Gołaszynie: A - piaskowiec z fauną małżów z niższej części (a) warstwy $2 ; \mathbf{B}$ - piaskowiec z fauną małżów z wyższej części (b) warstwy 2; $\mathbf{C}$ - amonit Erymnoceras z wyższej części warstwy 2; D - płytka cienka z piaskowca z wyższej części warstwy 2, skrzyżowane nikole

Fig. 3. Middle Callovian sandstones and fauna from excavation at Gołaszyn: A - sandstone with bivalves from lower part (a) of bed 2; $\mathbf{B}$ - sandstone with bivalves from upper part (b) of bed 2; C - ammonite Erymnoceras, upper part of bed 2; D - thin section of sandstone, upper part of bed 2, cross-polarized light

gólnymi walorami estetycznymi, co sprawiło, że stały się poszukiwane wśród kolekcjonerów. Brak ochrony prawnej i zainteresowania ośrodków muzealnych w kraju, aby powiększać istniejące kolekcje łukowskich skamieniałości, sprawiły, że duża część najcenniejszych okazów znalazła się w rękach prywatnych lub za granicą. Wartość okazów znacznie wzrosła, gdy zaprzestano eksploatacji iłów w cegielni na Łapiguzie, wyrobisko wypełniło się woda, a poszukiwaczom pozostały jedynie nieuzupełniane o nowy materiał stare hałdy, wyczerpujące się w szybkim tempie. Wtedy też pomyślano o podjęciu działań na rzecz ochrony tych cennych obiektów geologicznych. Z inicjatywy ostatniego dyrektora cegielni Łapiguz Czesława Zarzyckiego, podejmującego już w latach 60. ub.w. działania związane Z ratowaniem skamieniałości, i grupy działaczy ówczesnego łukowskiego Oddziału PTTK oraz wsparciu innych osób i organizacji (zobacz Zarzycki, 1989, 1996) utworzono rezerwat geologiczny Kra Jurajska (Zarządzenie, 1980, $\S 12$ ). Obejmuje on formalnie obszar o powierzchni 8 ha, w pobliżu granic Gołaszyna i Łukowa, gdzie również stwierdzono obecność kier podobnych do tych z Łapiguza. Celem ochrony rezerwatu jest zachowanie unikalnego złoża iłów jurajskich z licznymi skamieniałościami, głównie amonitów. Złoże to jednak zalega pod ziemią, a na powierzchni rozciągają się grunty rolne (łąki, grunty orne, pastwiska) - nie ma śladu istnienia skarbów dawnych mórz jurajskich. Na przełomie XX i XXI w. powstało kilka projektów zagospodarowania rezerwatu, które jednak $\mathrm{z}$ różnych powodów nie zostały zrealizowane.

Temat kier łukowskich powrócił w 2015 r. z inicjatywy Gminy Łuków i Lokalnej Grupy Działania Razem ku Lepszej Przyszłości, których władze zwróciły się do Państwowego Instytutu Geologicznego - Państwowego Instytutu Badawczego (PIG-PIB) z zapytaniem o możliwość wykorzystania tej osobliwości geologicznej, obecnie niemal zapomnianej, dla celów promocji gminy. W instytucie sprawę przekazano do Muzeum Geologicznego, które od lat inicjuje i współpracuje przy tworzeniu obiektów i planów zagospodarowania geoturystycznego w różnych rejonach Polski. W efekcie kilku spotkań pomiędzy przedstawicielami tych instytucji oraz przeprowadzenia wizji lokalnych w terenie, podpisano porozumienie o współpracy pomiędzy Gminą Łuków i PIG-PIB. Zakłada ono podejmowanie wspólnych działań zmierzających do zagospodarowania obszaru gminy Łuków dla celów naukowych, geoturystycznych i edukacyjno-rekreacyjnych oraz prowadzenie aktywnej edukacji geologicznej, w celu podniesienia świadomości społecznej - wszystko po to, aby z geologicznych osobliwości Łukowa uczynić instrument promujacy region. 
Muzeum Geologiczne przekazało wkrótce władzom gminy opracowanie zawierające propozycje działań geoekologicznych w gminie Łuków. Zakłada ono, że kra łukowska i znajdowane w niej amonity mają duży potencjał geoturystyczny i powinny stać się jednym z podstawowych, choć nie jedynym, elementem rozwoju turystycznego Łukowa i okolic. Ciekawymi obiektami geologicznymi na tym obszarze są również piaski eksploatowane w piaskowniach czy liczne głazy narzutowe. Został wykonany wstępny rekonesans do przygotowania lapidariów skalnych, na podstawie którego Gmina Łuków za pośrednictwem Lokalnej Grupy Działania Razem ku Lepszej Przyszłości aplikowała o fundusze na jego realizację. Aktualnie, po ich uzyskaniu rozpoczynają się prace przygotowawcze do stworzenia lapidariów w pięciu miejscowościach Gminy Łuków. Zwrócono również uwagę na - występujące w okolicy:

- wydmy będące świadectwem plejstoceńskiej i holoceńskiej działalności eolicznej z horyzontami kopalnych gleb;

- kopalne doliny rzeczne, których osady można obserwować w niektórych piaskowniach;

- meandrującą rzekę, która jest świadectwem działania erozji bocznej w korycie rzeki;

- towarzyszące dolinie starorzecza oraz torfy, będące przykładem akumulacji w starorzeczach.

W ramach współpracy zaproponowano podjęcie wielokierunkowych działań: od akcji informacyjnych dla lokalnej społeczności, poprzez udostępnianie dla turystów stanowisk geologicznych $\mathrm{w}$ formie pieszej lub rowerowej ścieżki geologicznej (wytypowano 10 stanowisk), projektów ekspozycji w dostępnych gminie obiektach użyteczności publicznej, wydanie publikacji dotyczących skamieniałości i obiektów geoturystycznych gminy Łuków, aż po koncepcję dużej, nowoczesnej ekspozycji w specjalnie wybudowanym pawilonie, udostępniającej rzeczywiste odsłonięcie utworów kry łukowskiej.

Działania rozpoczęto od akcji informacyjnych dla mieszkańców gminy. Muzeum Geologiczne przygotowało dla szkół gminy Łuków i przeprowadziło cykl zajęć warsztatowych z rozpoznawania skamieniałości, skał i minerałów oraz wykładów poświęconych tematyce plejstoceńskich zlodowaceń oraz środowiska życia w morzach jurajskich. Za pośrednictwem szkół, gmina przeprowadziła w formie konkursu zbiórkę skamieniałości łukowskiej fauny jurajskiej, z których następnie w reprezentacyjnym punkcie urzędu stworzono ekspozycję, $\mathrm{z}$ podaniem nazwisk darczyńców. Dla szerokiego grona odbiorców stworzono cykliczną imprezę popularonaukową $\mathrm{w}$ formie pikniku rodzinnego (ryc. 8, 9), w której co roku, poza Muzeum Geologicznym, biorą udział Lasy Państwowe (Nadleśnictwo Łuków), Muzeum Ziemi Łukowskiej oraz inne instytucje nauki, kultury i sztuki. Już po trzech latach wspólnych działań widoczne są efekty - identyfikacja społeczności z symbolem amonita: ruszył wyrób chleba z tym znaczkiem, a dzieci, które brały udział w warsztatach lub pikniku, wiedzą co to są amonity i skąd się wzięły na Ziemi Łukowskiej.

Na zlecenie Gminy Łuków Muzeum Geologiczne przygotowało folder Kry lukowskie - skarb z pótnocy. Historia geologiczna (Woroncowa-Marcinowska, 2017). Jest to cieszące się dużym zainteresowaniem wydawnictwo popularnonaukowe opisujące historię odkryć, genezę oraz znaczenie dla nauki kier łukowskich i skamieniałości w nich

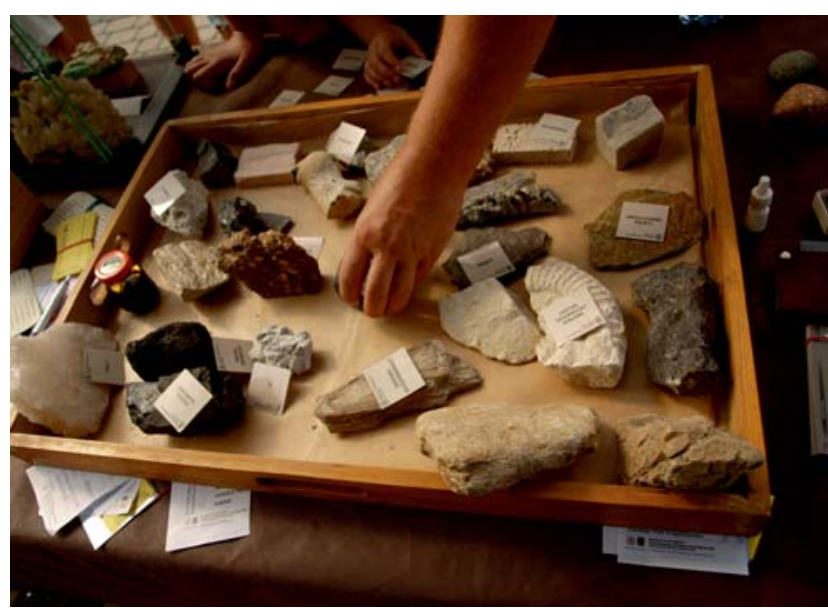

Ryc. 8. Stoisko Muzeum Geologicznego PIG-PIB podczas Jarmarku Geologicznego w Klimkach. Odwiedzający uczą się rozpoznawać minerały i skały

Fig. 8. Stand of the Geological Museum PGI-NRI during the Geological Fair in Klimki. Visitors learn to recognize different minerals and rocks

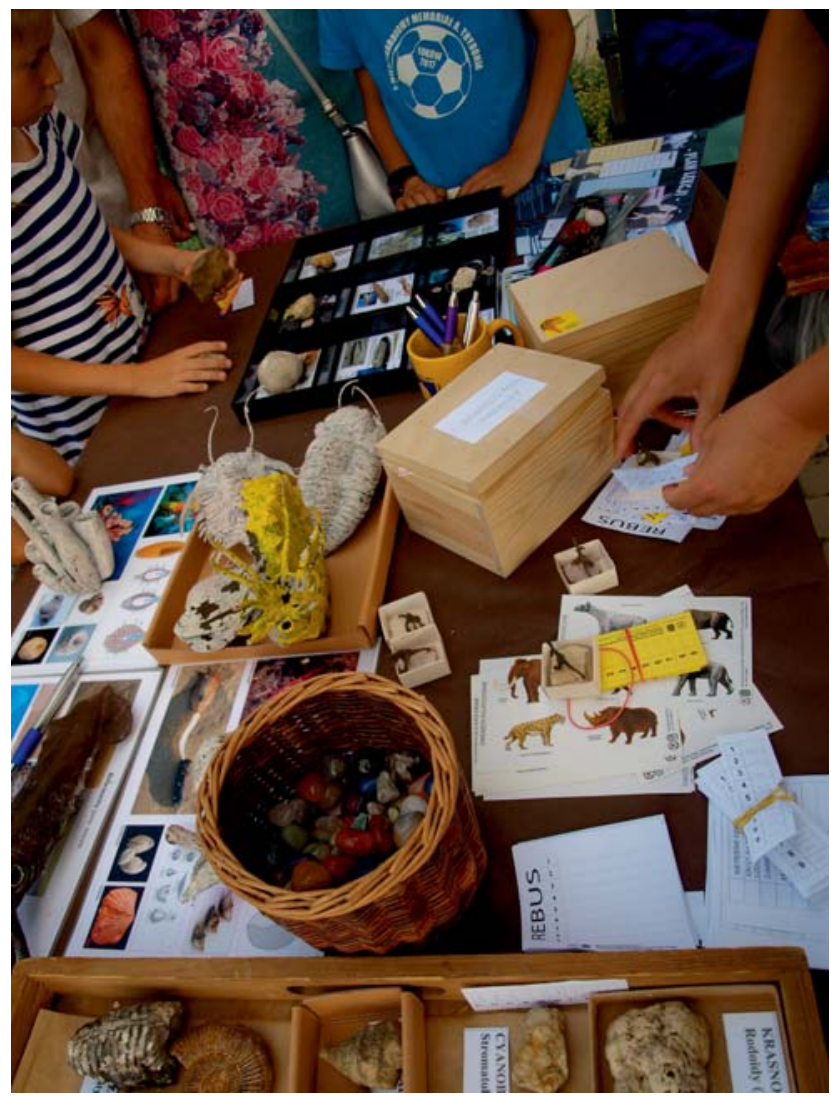

Ryc. 9. Konkursy i gry paleontologiczne dla dzieci prowadzone podczas jarmarku geologicznego. Obie fot. M. Krzeczyńska Fig. 9. Quizzes and paleontological games for children conducted during the Geological Fair. Both photos by. M. Krzeczyńska

zawartych. Wspólnymi siłami Urzędu Gminy Łuków i Muzeum Geologicznego zorganizowano na Ziemi Łukowskiej wspomniany wyżej 86. Zjazd Naukowy Polskiego Towarzystwa Geologicznego, który odbył się w początku września 2018 r. i zaowocował miedzy innymi nowym odkryciem w krze gołaszyńskiej, opisanym w niniejszym artykule.

Wszystkie te działania zwiazzane bezpośrednio lub pośrednio z pierwotnym celem - udostępnieniem odsłonięcia utworów kry łukowskiej odbiorcom, są jeszcze dalekie 
do osiagnięcia. Pierwszy, faktyczny krok przybliżający do niego został wykonany przy okazji przygotowywania odsłonięcia na 86. Zjazd Naukowy PTG. Wykop w Gołaszynie jest jedynym obecnie miejscem, gdzie można po raz pierwszy od zalania cegielni Łapiguz (ok. 1975 r.) obejrzeć osady jury (a prawdopodobnie i triasu) w okolicach Łukowa (ryc. 5, 6- patrz str. 714). Wartym rozważenia jest utworzenie w tym miejscu stanowiska dokumentacyjnego, które wpisałoby się w sieć geostanowisk o randze europejskiej. Aby spełniał on wymagane kryteria, niezbędnym będzie przeprowadzenie dalszych badań, w tym geotechnicznych. Stanowisko to powinno być dostępne dla nauki, a także przygotowane w odpowiedni - atrakcyjny i bezpieczny sposób, służyć edukacji i turystyce. Dlatego zasadnym wydaje się zlokalizowanie tu pawilonu ekspozycyjnego nazwanego Muzeum Kier Łukowskich (tytuł roboczy), pełniącego rolę centrum edukacyjnego, którego najważniejszym elementem będzie odpowiednio wyeksponowane i udostępnione odsłonięcie iłów kry łukowskiej z tkwiącymi w nich konkrecjami ze skamieniałościami. W muzeum powinny się znaleźć nowocześnie zaaranżowane, z wykorzystaniem multimediów, ekspozycje kompleksowo wyjaśniające najważniejsze zagadnienia związane $\mathrm{z}$ genezą kier lodowcowych (ekspozycja dotycząca zlodowaceń plejstoceńskich z modelem lądolodu), charakterystyką osadów występujących w krach i środowiskiem ich powstania oraz znaczeniem skamieniałości łukowskich dla nauki. Przede wszystkim nie powinno zabraknąć pełnej kolekcji fauny jurajskiej. Na potrzeby tej ekspozycji należałoby rozważyć możliwość zakupienia szczególnie wartościowych okazów od kolekcjonerów, a także ich wypożyczenia $\mathrm{z}$ istniejących państwowych i prywatnych muzeów geologicznych. Poza odsłonięciem, w ramach ekspozycji z całą pewnością wielkim zainteresowaniem będzie się cieszyć specjalnie wykonany wykop, umożliwiający prowadzenie samodzielnych poszukiwań paleontologicznych. Miejsce takie przyciagnie wielu entuzjastów szeroko pojętej geologii, ale również lokalną ludność, chętnie poznającą swoją gminę.

Przygotowanie takiego muzeum to poważne przedsięwzięcie inwestycyjne, a oszacowanie realnych kosztów jest zadaniem dla specjalistów. Należy się jednak spodziewać, że po dokonanym odkryciu dalsze działania na rzecz rozwoju geoturystyki w Gminie Łuków zyskają poparcie decydentów - taka okazja może się długo nie powtórzyć.

Aktualnie istnieją realne szanse wykorzystania potencjału geoturystycznego Gminy Łuków. Wymaga to współdziałania władz gminy, Towarzystwa Przyjaciół Ziemi Łukowskiej i Lokalnej Grupy Działania Razem ku Lepszej Przyszłości oraz pomocy instytucji naukowych. Obiekt powstały według powyższej koncepcji będzie stanowił doskonały cel dla różnych grup docelowych turystów: zorganizowanych wycieczkowych grup szkolnych, indywidualnych turystów preferujących turystykę kwalifikowaną oraz specjalistów znających wartość skamieniałości łukowskich, którzy od dawna ubolewają nad faktem, że tak istotne stanowisko dla polskiej i światowej geologii jest całkowicie niedostępne.

Autorzy składają serdeczne podziękowania recenzentom pracy - Annie Feldman-Olszewskiej i Piotrowi Migoniowi, za cenne uwagi wniesione do artykułu.

\section{LITERATURA}

ARKELL W.J. 1956 - Jurassic geology of the World. Oliver and Boyd Ltd., Edinburgh-London.

BRAND U. 1986 - Palaeoenvironmental analysis of Middle Jurassic (Callovian) ammonoids from Poland: trace elements and stable isotopes. J. Palaeont., 60: 293-301.

CALLOMON J.H., WRIGHT J.K. 1989 - Cardioceratid and kosmoceratid ammonites from the Callovian of Yorkshire. Palaeontology, 32 (4): 799-836.

GAŁAZKA D. 2004 - Zastosowanie metody makroskopowego oznaczania eratyków przewodnich do lokalizacji obszarów źródłowych wybranych kier jurajskich. Prz. Geol., 52 (4): 349-350.

GAŁAZKA D., MAŁEK M., MALESZYK M. 2009 - Sytuacja geologiczna i pochodzenie łukowskich kier jurajskich. [W:] M. Żarski S., Lisicki (red.), XVI Konferencja Stratygrafia plejstocenu Polski, Strefa marginalna zlodowacenia warty i pojezierza plejstoceńskie na południowym Podlasiu, Zimna Woda k. Łukowa 31.08-4.09.2009: 60-63.

GRIGELIS A., NORLING E. 1999 - Jurassic geology and foraminiferal faunas in the NW part of the East European Platform. A Lithuanian-Swedish geotraverse study. Research Papers, SGU series Ca 89: 1-88.

IWANOW A., ŠIMKEVIČIUS P., SUVEIZDIS P. 1998 - Triassic - stratigraphy and facies development. [W:] Marek S., Grigelis A., Atlas: Structural evolution of the Permian-Mesozoic complex of northeastern Poland, Lithuania and adjacent Baltic areas: 10-13.

JAHN A. 1950 - Nowe dane o położeniu kry jurajskiej w Łukowie. Ann. Soc. Geol. Pol., 19 (2): 371-386.

KOSMULSKA R. 1973 - Dane o nieznanych dotychczas wystappieniach iłów jurajskich w okolicach Łukowa. Prz. Geol., 21 (8/9): 440-441.

KRISZTAFOWICZ N., 1896, Jurskiye obrazowaniya w okriestnostiach goroda Łukowa, Sidlieckoj guberni, Jeżegodnik po Gieologii i Mineralogii Rossiji, t. 2: 8-13.

KULICKI C. 1979 - The ammonite shell: its structure, development and biological significance. Paleont. Polon., 39: 97-142.

KULICKI C. 1996 - Ammonoid shell microstructure. [W:] Landman N. in. (red.), Topics in Geology, 13: 65-101.

MAKOWSKI H. 1952 - La faune callovienne de Łuków en Pologne. Paleont. Polon., 4: 1-60.

MAKOWSKI H. 1962 - Problem of sexual dimorphism in ammonites. Paleont. Pol., 12: 1-92.

MAŁEK M., 2002 - Szczegółowa mapa geologiczna Polski 1 : 50 000, ark, Siedlce Południe (565). Min. Środ., Państw. Inst. Geol., Warszawa. MAŁEK M., BUCZEK K. 2011 - Szczegółowa mapa geologiczna Polski 1 : 50 000, ark. Łuków (602). Min. Środ., Państw. Inst. Geol., Warszawa. MATYJA B.A. 1986 - Developmental polymorphism in Oxfordian ammonites. Acta Geol. Polon., 36 (1-3): 37-68.

MIZERSKI W., SZAMAŁEK K. 1985 - Charakterystyka geologiczno-surowcowa kelowejskich skał ilastych kry lodowcowej w rejonie Gołaszyna k. Łukowa. Kwart. Geol., 29 (2): 369-392.

MENDECKI M., ŚWIDER M., NOWACZYŃSKA I., MAMAK A., ODROBIŃSKA J., PIOTROWSKA P., REWERS J., TYMIŃSKA A. 2018 - Geofizyczne rozpoznanie zasięgu kry jurajskiej w Gołaszynie k. Łukowa. Prz. Geol., 66 (1): 48-54.

MORAWSKI J. 1955 - Kra jurajska spod Łukowa w świetle prac wiertniczych. Prz. Geol., 3 (9): 440-442.

PIĄTKIEWICZ A. 1972 - Dokumentacja geologiczna w kat. $\mathrm{C}_{2}$ złoża iłu jurajskiego do produkcji keramzytu w rejonie miejscowości Gołaszyn, pow. Łuków, woj. Lublin. ZUGiT Kielce.

ROTKYTE L. 1987 - Amonity i zonalnaya stratigrafiya verkhneyurskikch otlozhenij Pribaltiki. Mokslas.Vilnius.

SALAMON M.A., ZATOŃ M., 2008 - New research on the classical Middle Jurassic locality at Łuków, eastern Poland. N. Jahrb.Geol. Paläont. Abh., 247 (2): 129-131.

WIERZBOWSKI A. 2018 - Jura łukowska - retrospekcja osiagnieć badawczych i nowe wyzwania. [W:] Mizerski W. i in. (red.), LXXXVI Zjazd Naukowy Polskiego Towarzystwa Geologicznego, Łuków 2-5 września 2018 r.: 30-32.

WORONCOWA-MARCINOWSKA T. 2017 - Kry łukowskie - skarb z północy. Historia geologiczna. Materiały promocyjne (folder). Państw. Inst. Geol., Warszawa.

ZATOŃ M. 2011 - Skarb z północy. Rocz. Muzeum Ewolucji, 3

ZARZĄDZENIE Ministra Leśnictwa i Przemysłu Drzewnego z dnia 15 grudnia 1980 r. w sprawie uznania za rezerwaty przyrody. M.P. $1980 \mathrm{nr}$ 30 poz. 171.

ZARZYCKI C. 1989 - Od Lapiguza do Gołaszyna - trudna droga do rezerwatu „Kra Jurajska”. Muzeum Regionalne w Łukowie, maszynopis: 1-5, niepublikowane.

ZARZYCKI C. 1996 - Przyczynek do utworzonego w 1980 r. rezerwatu przyrody „Kra Jurajska” w Gołaszynie. Muzeum Regionalne w Łukowie, maszynopis: $1-6$, niepublikowane.

Praca wpłynęła do redakcji 27.09.2018 r. Akceptowano do druku 12.10.2018 r. 


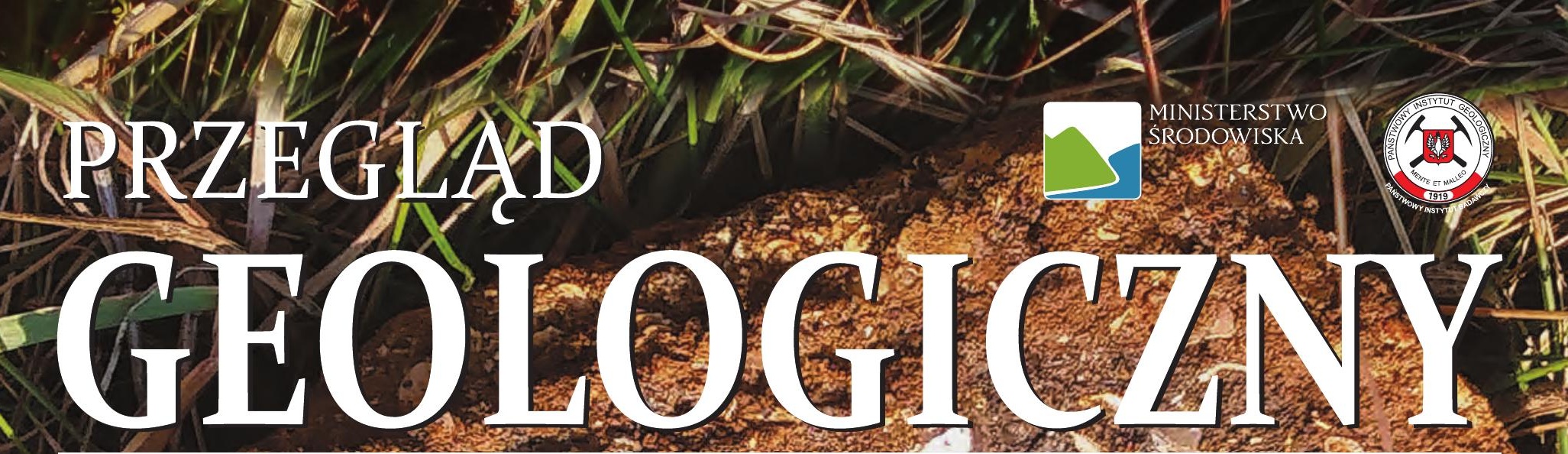
MRZECAAD

.

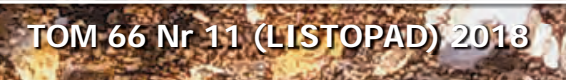

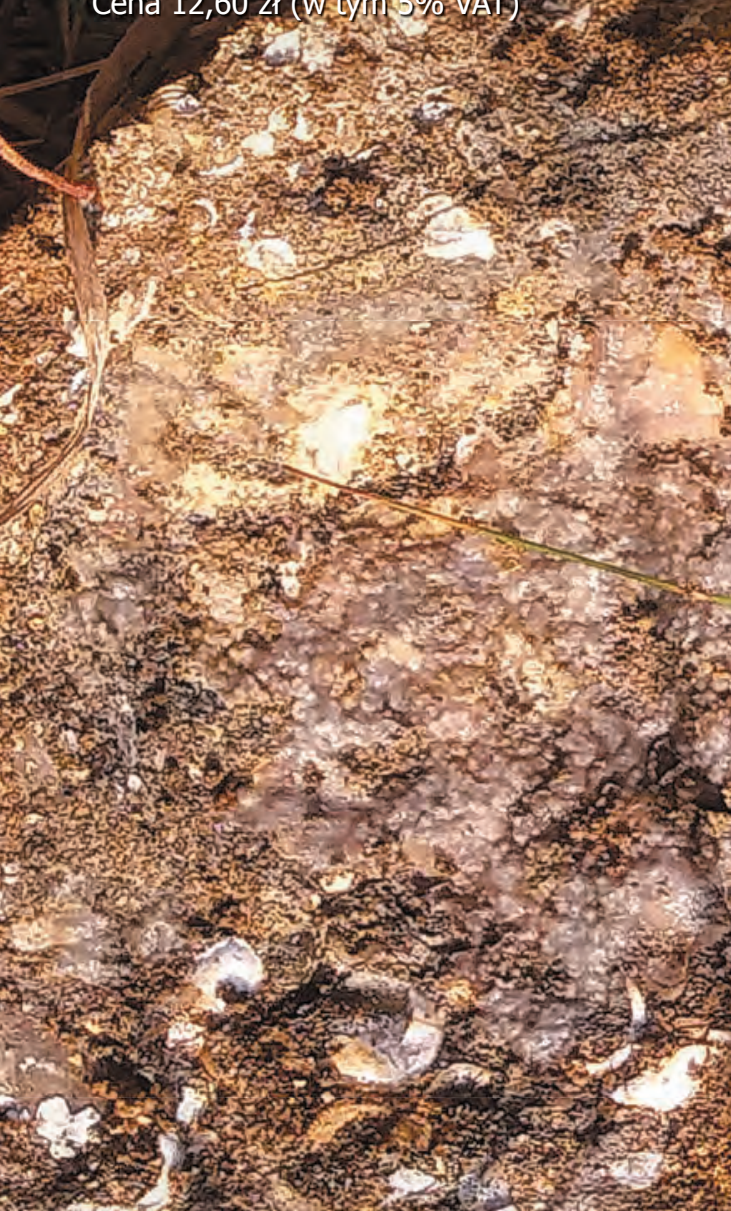

$\frac{1}{2}$

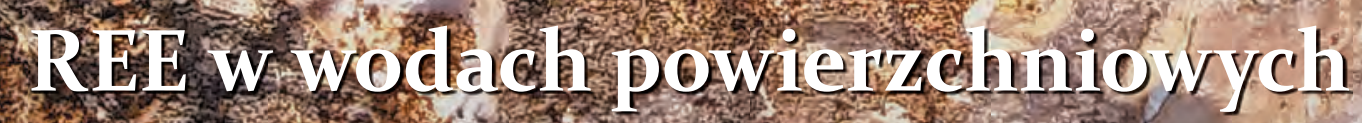
ipodzening in

Nowe odkrycie w krach mezozoicrny ch h Luk owa
Analiza sedaDNA w badaniach osadów czwartorzędowych

Polska geologia w okresie międzywojenlnym 
Zdjęcie na okładce: Płyta piaskowca z fauną małżów środkowego keloweju z wykopu w Gołaszynie - zobacz artykuł A. Wierzbowskiego i in. na str. 706. Fot. M. Krzeczyńska

Cover photo: A slab of the Middle Callovian sandstone with bivalves from excavation at Gołaszyn - see article by A. Wierzbowski et all on p. 706. Photo by M. Krzeczyńska 


\section{Nowe odkrycie w krach mezozoicznych w okolicach Lukowa i jego znaczenie dla promocji geoturystycznej regionu - patrz str. 706}

New discovery in glacially transported Mesozoic rock masses at Luków (eastern Poland), and its importance for the geotouristic promotion of the region - see p. 706

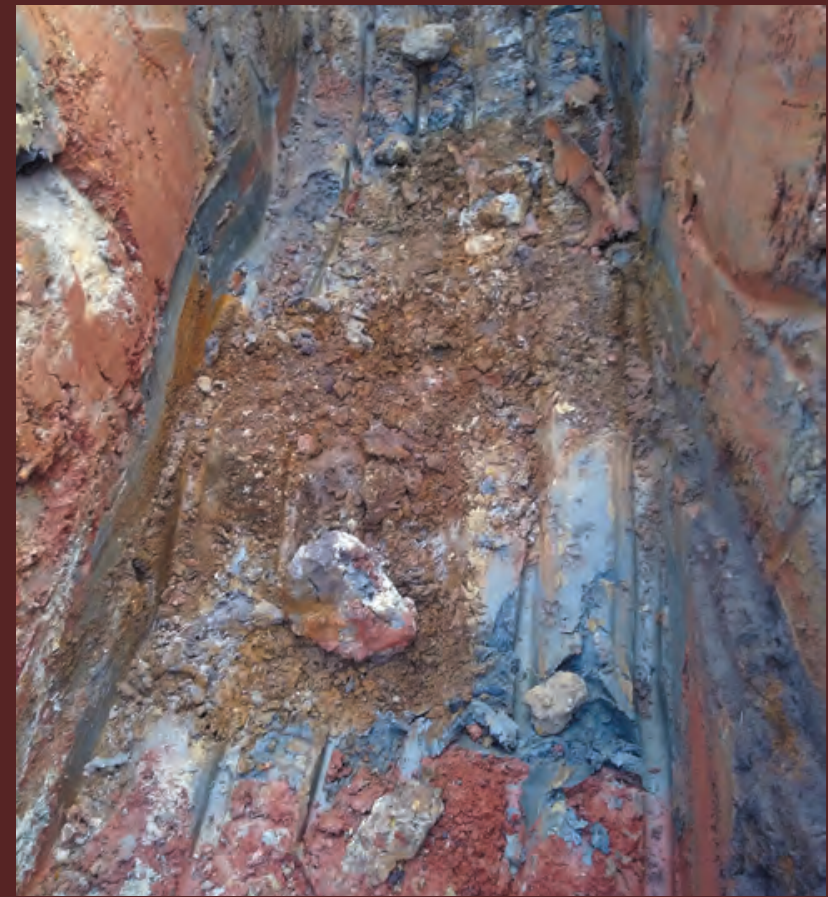

Ryc. 5. Wykop w Gołaszynie - część środkowa: powyżej czerwonych iłów triasu leżą brązowe oraz szare piaski i piaskowce środkowego keloweju, które są z kolei przykryte ciemnoszarymi iłami wyższego keloweju

Fig. 5. Excavation at Gołaszyn - middle part: the Triassic red clays are overlain by brownish and gray sands and sandstones of the Middle Callovian, and the succeeding gray and dark-gray clays of a higher Callovian

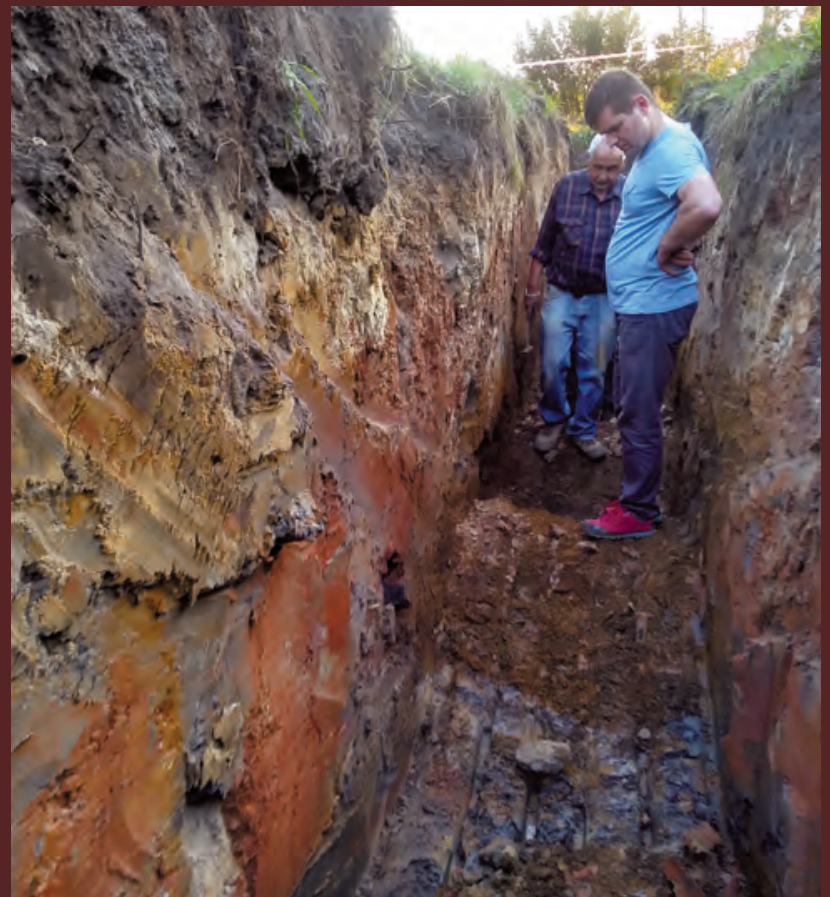

Ryc. 6. Wykop w Gołaszynie - część północna: powyżej ciemnoszarych iłów keloweju (widocznych także w stropie sukcesji na ryc. 5) widoczne są nasunięte glacitektonicznie czerwone iły triasu

Fig. 6. Excavation at Gołaszyn - northern part: the Triassic red clays are glacitectonically overthrust on the Callovian dark-gray clays (the latter are seen also in the upper part of the succession in Fig. 5)

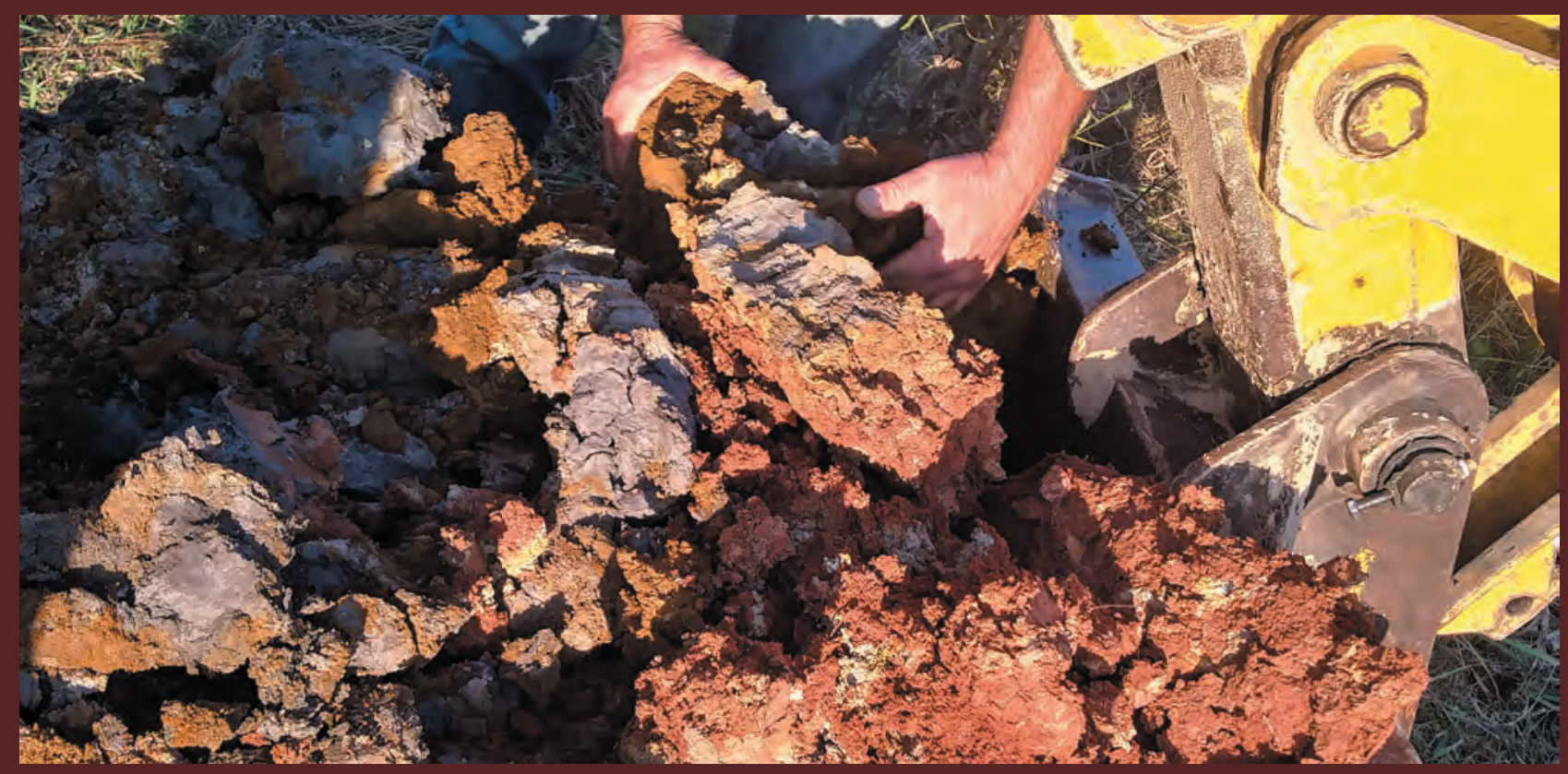

Ryc. 7. Czerwone iły triasu (z prawej) i ciemnoszare iły keloweju (z lewej) wydobyte z wykopu w Gołaszynie. Wszystkie fot. M. Krzeczyńska

Fig. 7. Red Triassic clays (on the right), and dark-gray Callovian clays (on the left) derived from the excavation at Gołaszyn. All photos by M. Krzeczyńska 